\title{
POTENTIAL IMMUNOLOGICAL MARKERS FOR DIAGNOSIS AND THERAPEUTIC ASSESSMENT OF TOXOCARIASIS
}

Guita RUBINSKY-ELEFANT(1), Sumie HOSHINO-SHIMIZU(1), Cristina Miuki Abe JACOB(2), Maria Carmen Arroyo SANCHEZ(1) \& Antonio Walter FERREIRA(3)

\begin{abstract}
SUMMARY
In human toxocariasis, there are few approaches using immunological markers for diagnosis and therapeutic assessment. An immunoblot (IB) assay using excretory-secretory Toxocara canis antigen was standardized for monitoring $\operatorname{IgG}, \operatorname{IgE}$ and $\operatorname{IgA}$ antibodies in 27 children with toxocariasis (23 visceral, three mixed visceral and ocular, and one ocular form) for 22-116 months after chemotherapy. IB sensitivity was $100 \%$ for IgG antibodies to bands of molecular weight 29-38, 48-54, 95-116, 121-162, $>205 \mathrm{kDa}$, 80.8\% for IgE to 29-38, 48-54, 95-121, > $205 \mathrm{kDa}$, and $65.4 \%$ for IgA to 29-38, 48-54, 81-93 kDa. Candidates for diagnostic markers should be IgG antibodies to bands of low molecular weight (29-38 and 48-54 kDa). One group of patients presented the same antibody reactivity to all bands throughout the follow-up study; in the other group, antibodies decayed partially or completely to some or all bands, but these changes were not correlated with time after chemotherapy. Candidates for monitoring patients after chemotherapy may be IgG antibodies to $>205 \mathrm{kDa}$ fractions, IgA to $29-38,48-54,81-93 \mathrm{kDa}$ and IgE to $95-121 \mathrm{kDa}$. Further identification of antigen epitopes related to these markers will allow the development of sensitive and specific immunoassays for the diagnosis and therapeutic assessment of toxocariasis.
\end{abstract}

KEYWORDS: Toxocariasis; Immunoblot assay; Immunoglobulin isotypes; Chemotherapy.

\section{INTRODUCTION}

Human toxocariasis, a zoonotic disease caused by larvae of the dog ascarid worm, Toxocara canis, and less frequently by those of the cat ascarid, Toxocara cati, is found worldwide. In humans, these infecting nematode larvae are unable to complete their own developmental life cycle and propagation ${ }^{6,7,21}$. Nevertheless, the larvae migrate through different organs, shedding immunogenic glycoproteins, known as Toxocara excretory-secretory (TES) antigens. These antigens seem to allow larvae to evade and survive under the adverse conditions of the host's immune response ${ }^{5}$. The clinical symptoms vary as a consequence of larvae migration, ranging from asymptomatic forms to those with severe organ injuries.

There are two main clinical forms: visceral toxocariasis and ocular toxocariasis. Covert toxocariasis has been described as presenting non-specific symptoms, such as abdominal pain, headache, cough and limb pains. In some instances, neurological manifestations have been associated with the presence of Toxocara larvae in the brain ${ }^{9,12}$.

In the absence of parasitological evidence of infection, immunological methods play a relevant role in the diagnosis of toxocariasis. The detection of IgG antibodies with the TES-based enzyme-linked immunosorbent assay (ELISA) is the preferred method $^{3}$. In follow-up studies after chemotherapy, however, these IgG antibodies were observed to be unsuitable as an immunological marker for therapeutic assessment, because they remained persistently for years ${ }^{4,22}$, as occurs in most parasitic infections ${ }^{15}$. In our previous work, IgG antibodies detected by ELISA were found to be appropriate for serological diagnosis of toxocariasis, and IgE antibodies in conjunction with eosinophil counts were helpful parameters for monitoring patients after chemotherapy ${ }^{4}$.

The immunoblot (IB) technique has been shown to be a useful tool for many immunologic approaches in different diseases. However, there are few follow-up studies in patients after chemotherapy showing changes in their IB patterns, according to antibody isotypes and antigen fractions. For toxocariasis, there have been attempts to find the most suitable antigens or refined antigen epitopes for immunoassays ${ }^{1,11,16}$. There is a need to standardize serodiagnostic criteria and define the efficacy of chemotherapy ${ }^{23}$.

In the present work, patients with toxocariasis were studied before and after chemotherapy, in the search for potential immunological markers for both diagnosis and therapeutic assessment. The IB patterns developed by different antibody isotypes ( $\mathrm{IgG}, \mathrm{IgA}$ and $\mathrm{IgE}$ ) to TES

(1) Laboratório de Soroepidemiologia e Imunobiologia, Instituto de Medicina Tropical de São Paulo, São Paulo, SP, Brasil.

(2) Departamento de Pediatria, Faculdade de Medicina, Universidade de São Paulo, São Paulo, SP, Brasil.

(3) Departamento de Moléstias Infecciosas e Parasitárias, Faculdade de Medicina, Universidade de São Paulo and Instituto de Medicina Tropical de São Paulo, São Paulo, SP, Brasil.

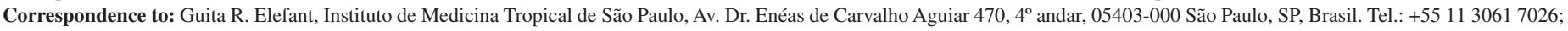
fax: +55 113061 8270. E-mail: guitare@usp.br 


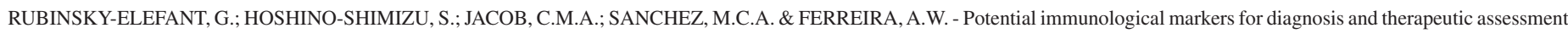
of toxocariasis. Rev. Inst. Med. Trop. Sao Paulo, 53(2): 61-5, 2011.

antigen fractions were investigated, following up patients before and after chemotherapy.

This project was approved by the "Comitê de Ética em Pesquisa" of the "Instituto de Medicina Tropical de São Paulo" and the "Instituto da Criança do Hospital das Clínicas da Faculdade de Medicina da Universidade de São Paulo", and by the "Comissão de Ética em Pesquisas com Seres Humanos" of the "Instituto de Ciências Biomédicas da Universidade de São Paulo".

\section{MATERIALS AND METHODS}

Toxocara canis excretory-secretory antigen (TES): This antigen was prepared as described previously by ELEFANT et $a l .{ }^{4}$ from the supernatant of a concentrated culture of $T$. canis larvae, with quality control analysis to ensure the reproducibility of the immunologic assays.

Ascaris suum adult worm extract (AWE): Non-specific antibodies were removed by serum absorption with AWE. This antigenic extract was obtained from A. suum, according to ELEFANT et al. ${ }^{4}$.

Patients and serum samples: Serum samples from 27 children with toxocariasis ( 23 with the visceral form, three with mixed visceral and ocular forms, and one with the ocular form), aged from one to 12 years, were collected before and after chemotherapy, annually for a period of up to nine years. Patients were treated with thiabendazole $(25 \mathrm{mg} / \mathrm{kg}$ per day) for seven days. In the ocular cases, corticotherapy was also administered (prednisone - $1 \mathrm{mg} / \mathrm{kg}$ per day). The diagnosis was based on clinical, epidemiologic and laboratory findings. Before treatment, all patients presented anti-Toxocara IgG antibodies detected by ELISA, and all of those with visceral toxocariasis presented eosinophilia $\geq 10 \%$. The main clinical symptoms were: pulmonary manifestations in $73.9 \%$ of the patients, asthma and/or rhinitis in $56.5 \%$ and fever in $39.1 \%$. In patients with ocular toxocariasis, uveitis and retinal detachment of the right eye were the main clinical manifestations. Serum samples from nine clinically healthy individuals were collected for use as negative controls.

Immunoblot (IB) procedure: The TES antigen $(1.5 \mu \mathrm{g} / \mathrm{mm})$ was fractionated by means of sodium dodecyl sulfate-polyacrylamide gel electrophoresis (SDS-PAGE) on a 5-15\% gel gradient ${ }^{10}$, and was transferred electrophoretically to $0.22-\mu \mathrm{m}$ pore size nitrocellulose membranes (Millipore Corp., Bedford, MA) ${ }^{24}$. The membranes were cut into strips 3-4 mm wide, blocked for 30 min at $37^{\circ} \mathrm{C}$ with $1 \%$ skim milk (Molico, Nestle, Araçatuba, São Paulo, Brazil) in phosphate-buffered saline containing $0.05 \%$ Tween 20 (PBS-T). The serum samples were diluted 1/100 for IgG-IB and $1 / 20$ for both IgA and IgE-IB with $1 \%$ skim milk in PBS-T, and strips were incubated for $18 \mathrm{~h}$ at $4{ }^{\circ} \mathrm{C}$. All serum samples had been pre-absorbed with AWE $(25 \mu \mathrm{g} / \mathrm{mL})$ in PBS-T for $30 \mathrm{~min}$ at $37^{\circ} \mathrm{C}$. For IgE-IB, serum samples had been also pre-absorbed with RF-absorbent ( $\mathrm{v} / \mathrm{v})$ (Dade Behring, Marburg, Germany) for $18 \mathrm{~h}$ at $4{ }^{\circ} \mathrm{C}$, in order to enhance the detection of $\mathrm{IgE}$ antibodies. After washing, the strips were incubated for two $\mathrm{h}$ at $37{ }^{\circ} \mathrm{C}$ with peroxidase conjugates diluted in $1 \%$ skim milk in PBS-T as follows: 1/1000 dilution for anti-human IgG (Biolab Diagnostic, Rio de Janeiro, Brazil); 1/200 dilution for anti-human IgA (Dako, Denmark); and 1/160 dilution of anti-human IgE (Sigma Chemical Co, St Louis, MO, USA). Then the strips were washed and treated with 4-chloro- $\alpha$-naphthol ( $0.05 \%$ in methanol) and $0.8 \mu \mathrm{L} / \mathrm{mL} \mathrm{H}_{2} \mathrm{O}_{2} 30 \%$. After 15 min the reaction was interrupted with distilled water.
Statistical analysis: Comparisons between proportions were made using Fisher's exact test or chi-square test $\left(\chi^{2}\right)$. Comparisons between times when antibodies partially or completely decayed were made by Kruskal-Wallis analysis of variance, and the verification of differences between groups was evaluated by multiple comparison Student-NewmanKeuls. The significance levels of the tests were fixed by accepting a type 1 error of $5 \%(\alpha=0.05)$ (SigmaStat 1.0).

\section{RESULTS}

The analysis of the results was conducted on serum samples from 26 patients ( 23 visceral + three mixed visceral and ocular). Because we studied only one patient with ocular toxocariasis, these results are merely descriptive. In the group of nine clinically healthy individuals, specific $\mathrm{IgG}, \mathrm{IgE}$ and $\mathrm{Ig} \mathrm{A}$ antibodies were not detected.

Immunoblot for IgG (IgG-IB): Before treatment, IgG antibodies were detected in all patients, corresponding to a $100 \%$ sensitivity, predominantly to the following TES protein antigens: molecular weight (MW) 29-38, 48-54, 95-116, 121-162 and > 205 kDa (Fig. 1A). After chemotherapy, patients were separated into two groups according to their IgG-IB patterns: the first group consisted of $11(42.3 \%)$ patients who presented the same IgG antibody reactivity to all bands throughout the period of our study; the second group of $15(57.7 \%)$ patients presented changes (i.e., antibodies decayed partially or completely to some or all bands) but these changes were not correlated with time after chemotherapy (Fisher's exact test $p=1.0$ ) (Table 1). The antibodies to the $>205 \mathrm{kDa}$ bands completely disappeared (after two-seven years) in $10(38.5 \%)$ patients, which was statistically significant when compared with the other bands $\left(\chi^{2}, p<0.05\right)$.

Immunoblot for IgE (IgE-IB): Before treatment, specific IgE antibodies were found in $21(80.8 \%)$ patients with toxocariasis, and these reacted mostly with TES protein antigens of MW 29-38, 48-54, $66,95-121$ and $>205 \mathrm{kDa}$ (Fig. 1B).These 21 patients were separated according to their IgE-IB patterns, similar to the criterion adopted for IgG-IB patterns. The first group of six $(28.6 \%)$ patients had no changes in $\mathrm{IgE}$ antibody reactivity before and after treatment. In the second group, $15(71.4 \%)$ patients presented changes that were not correlated with time after chemotherapy (Fisher's exact test, $p=0.6351$ ) (Table 1). In $12(57.1 \%)$ patients, antibodies to $95-121 \mathrm{kDa}$ bands completely disappeared after two-seven years, but this was not statistically significant when compared with the other bands $\left(\chi^{2}, p=0.1404\right)$.

Immunoblot for IgA (IgA-IB): Before treatment, IgA antibody reactivity, observed in $17(65.4 \%)$ patients with toxocariasis, was predominantly with TES antigens of MW 29-38, 48-54, 66 and 81-93 $\mathrm{kDa}$ (Fig. 1C). These 17 patients were grouped according to their IgA-IB patterns. Two (11.8\%) patients had no changes in their post-treatment IgA antibody patterns, and $15(88.2 \%)$ patients presented changes that were not correlated with time after chemotherapy (Fisher's exact test, $p=1.0$ ) (Table 1). All bands completely disappeared in $12(70.6 \%)$ patients, and considering at least one of the three clusters, the antibodies disappeared in $15(88.2 \%)$ patients.

Patient with ocular toxocariasis: $\mathrm{IgG}$ remained unchanged during the 46 months follow-up after chemotherapy, $\operatorname{IgA}$ reactivity diminished for all bands after 24 months, and IgE antibodies were not detected (Fig. 1 and Table 1). 


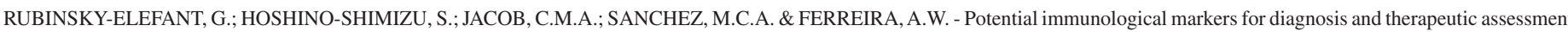
of toxocariasis. Rev. Inst. Med. Trop. Sao Paulo, 53(2): 61-5, 2011.

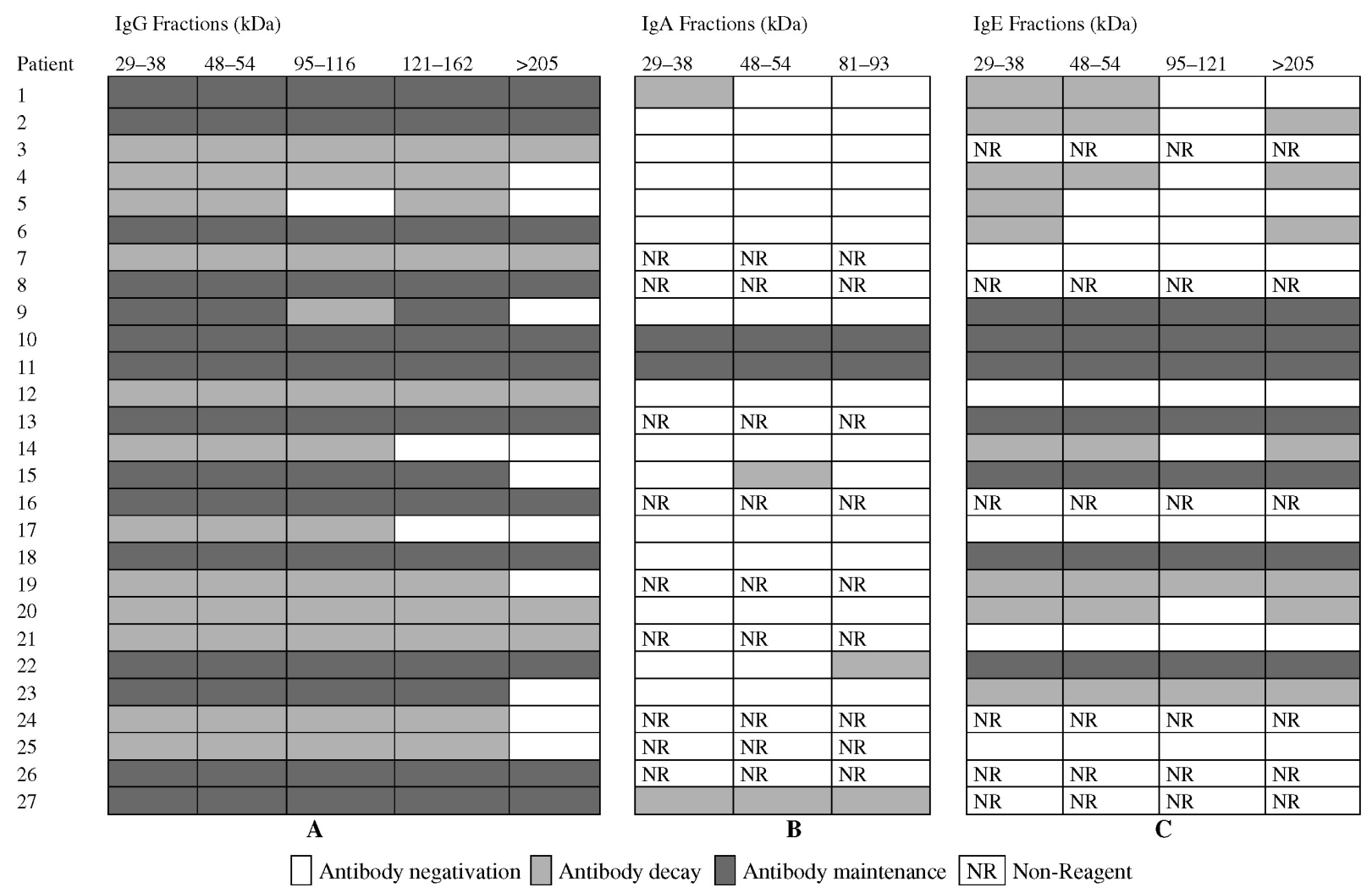

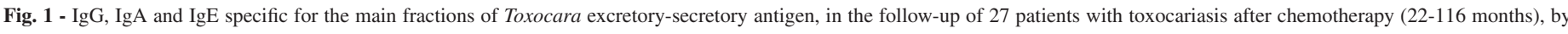
immunoblot assay. Toxocariasis patients: 1 to 23, visceral form; 24-26, mixed visceral and ocular; 27, ocular.

Overall data: $\operatorname{IgG}, \operatorname{Ig} \mathrm{A}$ and $\operatorname{IgE}$ antibodies to the $66-\mathrm{kDa}$ antigen were detected in some patients and remained reactive throughout the study, but they are unspecific ${ }^{17}$. Patients were divided into two groups according to the time after chemotherapy when changes in band patterns were observed. For IgG and IgE antibodies, the time was four years, and for IgA it was two years. In all cases no differences were observed (Fisher's exact test, $p>0.05$ ).

Sixteen $(61.5 \%)$ patients were reactive to all immunoglobulin classes. Two patients showed the same reactivity to all bands throughout the study period, and for the other 14, the antibodies decayed partially and/or completely for some or all bands. The changes in reactivity (i.e., antibodies decayed partially and/or completely) were observed earlier for IgA antibodies (Kruskal-Wallis, $p=0.0334$ ) compared with IgG and IgE (Student-Newman-Keuls method, $p<0.05$ ).

\section{DISCUSSION}

Many immunologic aspects have been investigated in human toxocariasis using the IB technique, but there are few studies on immunological markers for diagnosis, therapeutic assessment or prognosis. Our results show some similarities to and discrepancies from reported findings $s^{1,11,16}$, although some studies used different immunological approaches for toxocariasis.

Different factors, such as TES antigen preparations, parasite strains, and IB technical procedures, seem to influence the results obtained by different investigators ${ }^{1}$.

Before treatment, all patients with toxocariasis (visceral, ocular and mixed forms) showed IgG-IB positive results, in agreement with the data we have obtained previously by the IgG-ELISA ${ }^{4}$. In the IgG-IB, sera from patients with toxocariasis recognized most of the protein bands, ranging from 29 to $>205 \mathrm{kDa}$. NUNES et al. ${ }^{17}$ found MW 29-35, 50-55, 97-116, 200-210 kDa fractions, which were similar to ours in IgG-IB: MW 29$38,48-54,66,95-116,121-162$ and > $205 \mathrm{kDa}$. Although BADLEY et al. ${ }^{1}$ considered individual bands (at least 15 bands between 29 and 94 $\mathrm{kDa}$ and four to six bands $>200 \mathrm{kDa}$ ), our findings were consistent with theirs. MAGNAVAL et al. ${ }^{11}$ observed seven bands $(24,28,30,35,132$, 147 and $200 \mathrm{kDa})$ and ROLDÁN et al. ${ }^{20}$ detected 10 bands $(24,28,30$, $35,48,56,67,117,136$ and $152 \mathrm{kDa})$. The intermediate bands (95-116 and $121-162 \mathrm{kDa}$ ) found in the present study were not described by the other investigators ${ }^{1,11,17,20}$, and deserve to be further studied. Technical peculiarities used in TES production or the IB procedure may be the cause of such differences ${ }^{1,17}$.

We found antibodies to the $66 \mathrm{kDa}$ band, which was persistently reactive and considered unspecific, based on previous data ${ }^{8,14,17}$. This protein has epitopes in common with Ascaris sp. disappearing after absorption with A. suum antigen ${ }^{17}$.

In the follow-up study of patients after chemotherapy, the 
Table 1

Follow-up time and specific IgG, IgA and IgE antibody negativity/decay time, by immunoblot assay, in 27 patients with toxocariasis

\begin{tabular}{|c|c|c|c|c|}
\hline \multirow[t]{2}{*}{ Patient } & \multirow{2}{*}{$\begin{array}{l}\text { Follow-up time } \\
\quad \text { (months) }\end{array}$} & \multicolumn{3}{|c|}{ Antibody negativity/decay time (months) } \\
\hline & & $\mathrm{IgG}$ & $\operatorname{Ig} \mathrm{A}$ & $\operatorname{IgE}$ \\
\hline 1 & 46 & $*$ & 19 & 46 \\
\hline 2 & 94 & $*$ & 28 & 47 \\
\hline 3 & 37 & 28 & 28 & NR \\
\hline 4 & 89 & 42 & 20 & 42 \\
\hline 5 & 98 & 47 & 22 & 22 \\
\hline 6 & 62 & $*$ & 38 & 38 \\
\hline 7 & 86 & 86 & NR & 86 \\
\hline 8 & 40 & $*$ & NR & NR \\
\hline 9 & 62 & 40 & 19 & $*$ \\
\hline 10 & 51 & $*$ & $*$ & $*$ \\
\hline 11 & 22 & $*$ & $*$ & $*$ \\
\hline 12 & 71 & 64 & 71 & 71 \\
\hline 13 & 25 & $*$ & $\mathrm{NR}$ & $*$ \\
\hline 14 & 48 & 48 & 48 & 48 \\
\hline 15 & 61 & 28 & 28 & 28 \\
\hline 16 & 57 & $*$ & NR & NR \\
\hline 17 & 93 & 54 & 54 & 54 \\
\hline 18 & 68 & $*$ & 56 & $*$ \\
\hline 19 & 116 & 64 & NR & 64 \\
\hline 20 & 27 & 27 & 27 & 27 \\
\hline 21 & 76 & 76 & NR & 76 \\
\hline 22 & 57 & $*$ & 29 & $*$ \\
\hline 23 & 102 & 22 & 22 & 22 \\
\hline 24 & 82 & 82 & NR & NR \\
\hline 25 & 91 & 73 & NR & 73 \\
\hline 26 & 48 & $*$ & $\mathrm{NR}$ & NR \\
\hline 27 & 46 & $*$ & 24 & NR \\
\hline
\end{tabular}

Patients: 1 to 23, visceral form; 24 to 26, mixed visceral and ocular; 27, ocular. NR, non-reagent. *Antibody maintenance during follow-up after chemotherapy.

disappearance of specific $\operatorname{IgG}$ antibodies reactive to protein bands > $205 \mathrm{kDa}$ may be indicative of success of chemotherapy. Therefore, we are now studying the performance of specific IgG subclasses (IgG1, 2, 3 and 4) for these high MW bands.

The IgE-IB patterns developed by patients before treatment were similar to those of IgG-IB, except for the absence of 121-162 kDa bands, data consistent with those reported by OBWALLER et al. ${ }^{18}$. Sera from two patients with mixed forms and one patient with the ocular form of toxocariasis were negative by the IgE-IB, confirming our previous negative findings by immunoenzymatic assay $(\operatorname{IgE})^{4}$. In the ocular form of the disease, the detection of specific $\operatorname{IgE}$ in aqueous fluid and serum has been suggested by some authors ${ }^{13}$ to give more sensitive results, using $\mathrm{IgE}-\mathrm{IB}$ in combination with immunoenzymatic assay (IgE). However, aqueous fluids are seldom available in the laboratory.

We detected specific IgE antibodies in $21(80.8 \%)$ patients with toxocariasis using the IB technique, and this finding is considerably higher than the positivity found previously in immunological studies of toxocariasis by OBWALLER et al. ${ }^{18}$. This high positivity of the IgE-IB technique may be due to the depletion of $\mathrm{IgG}$ antibodies beforehand with the RF absorbent.

There are few studies on $\operatorname{IgA}$ antibodies, even in other parasitic infections, however, they have been detected in at least two different conditions: (a) in the acute phase of the infection, disappearing afterwards, as in toxoplasmosis ${ }^{2}$ and (b) in the chronic phase, as in schistosomiasis mansoni and the digestive form of Chagas disease ${ }^{19}$, in which $\operatorname{Ig}$ A antibodies last for a long period of time. The latter process is not well understood, but when the mucosal lesion is not well resolved by the local $\operatorname{IgA}$, it seems that serum $\operatorname{IgA}$ antibody levels increase and remain elevated for a long period of time. This may be one explanation why $\operatorname{IgA}$ antibodies were detected in $65.4 \%$ of our patients.

To the best of our knowledge, this is the first time that IgA-IB patterns have been studied in toxocariasis. The patterns developed by patients before treatment were similar to those of IgG-IB, except for the absence of high MW bands above $93 \mathrm{kDa}$, and these results need to be further studied. After chemotherapy, the total absence of antibodies to these antigenic bands may be associated with therapeutic efficacy.

The overall data demonstrate that antibody isotypes have different IB patterns. For diagnosis, IgG is the best marker as it was detected in all patients with visceral, ocular and mixed forms of the disease. Low MW bands, described by other researchers ${ }^{11,20}$ as specific, may be targets for IgG antibody detection in the diagnosis of toxocariasis. For monitoring patients after chemotherapy, IgG to $>205 \mathrm{kDa}$ fractions, IgA to 29-38, 48-54, 81-93 kDa and IgE to 95-121 kDa may be useful.

The maintenance of specific antibody levels, especially IgG and IgE isotypes, observed throughout the follow-up study after chemotherapy may be due to factors such as the parasite burden, reinfection or even larval reactivation ${ }^{4}$. These factors may also influence the lack of correlation between antibody level decay and time after chemotherapy.

Toxocariasis is a cosmopolitan zoonosis and reliable assays, highly sensitive and specific, for diagnosis and therapeutic evaluation are required in public health programs. These findings seem promising and may provide a framework for investigating further epitopes and represent a valuable contribution to immunological markers for diagnosis and therapeutic assessment.

\section{RESUMO} Estudo de marcadores imunológicos para o diagnóstico e avaliação
terapêutica da toxocaríase

Métodos imunológicos desempenham papel importante no 
RUBINSKY-ELEFANT, G.; HOSHINO-SHIMIZU, S.; JACOB, C.M.A.; SANCHEZ, M.C.A. \& FERREIRA, A.W. - Potential immunological markers for diagnosis and therapeutic assessment of toxocariasis. Rev. Inst. Med. Trop. Sao Paulo, 53(2): 61-5, 2011.

diagnóstico da toxocaríase, entretanto há poucos estudos sobre marcadores diagnósticos e de acompanhamento terapêutico. Foi padronizado ensaio de immunoblot (IB) empregando antígeno de excreção-secreção de Toxocara canis para pesquisa de anticorpos IgG, IgE e IgA em 27 crianças com toxocaríase nas formas visceral (23), mista visceral e ocular (3) e ocular (1), por 22-116 meses após quimioterapia. Foram observados dois perfis de reatividade dos anticorpos: permanência contra todas as frações no decorrer do estudo; diminuição ou negativação contra algumas ou todas as frações, porém, essas mudanças não se correlacionaram com tempo de tratamento. A sensibilidade do IB foi $100,0 \%$ para anticorpos IgG específicos para frações de massa molecular de 29-38, 48-54, 95-116, 121-162, > 205 kDa, 80,8\% para IgE específicos para 29-38, 48-54, 95-121, > $205 \mathrm{kDa}$ e 65,4\% para IgA específicos para 29-38, 48-54, 81-93 kDa. Anticorpos IgG específicos para frações de baixa MM (29-38 e 48-54 kDa) podem ser sugeridos como candidatos a marcadores diagnósticos. Por sua vez, anticorpos IgG para fração > 205 $\mathrm{kDa}$, IgA para 29-38, 48-54, 81-93 kDa e IgE para 95-121 kDa podem ser candidatos a marcadores terapêuticos. A identificação de epítopos antigênicos relacionados a estes marcadores poderá ser importante para o desenvolvimento de ensaios altamente sensíveis e específicos no diagnóstico e avaliação terapêutica da toxocaríase.

\section{ACKNOWLEDGEMENTS}

Supported by the Laboratório de Investigação Médica em Imunologia (LIM-48) and Hospital das Clínicas, Faculdade de Medicina, Universidade de São Paulo.

\section{REFERENCES}

1. Badley JE, Grieve RB, Bowman DD, Glickman LT, Rockey JH. Analysis of Toxocara canis larval excretory-secretory antigens: physicochemical characterization and antibody recognition. J Parasitol. 1987;73:593-600.

2. Decoster A, Caron A, Darcy F, Capron A. IgA antibodies against P30 as markers of congenital and acute toxoplasmosis. Lancet. 1988; 2:1104-7.

3. De Savigny DH, Voller A, Woodruff AW. Toxocariasis: serological diagnosis by enzyme immunoassay. J Clin Pathol. 1979;32:284-8.

4. Elefant GR, Shimizu SH, Sanchez MCA, Jacob CMA, Ferreira AW. A serologica follow-up of toxocariasis patients after chemotherapy based on the detection of $\mathrm{IgG}$, $\mathrm{IgA}$ and IgE antibodies by enzyme-linked immunosorbent assay. J Clin Lab Anal. 2006;20:164-72.

5. Gems D, Maizels RM. An abundantly expressed mucin-like protein from Toxocara canis infective larvae: the precursor of the larval surface coat glycoproteins. Proc Natl Acad Sci USA. 1996;93:1665-70.

6. Glickman LT, Schantz PM. Epidemiology and pathogenesis of zoonotic toxocariasis. Epidemiol Rev. 1981;3:230-50.

7. Hotez PJ, Wilkins PP. Toxocariasis: America's most common neglected infection of poverty and a helminthiasis of global importance? PLoS Negl Trop Dis. 2009;3:e400.

8. Ishida MMI, Rubinsky-Elefant G, Ferreira AW, Hoshino-Shimizu S, Vaz AJ. Helminth antigens (Taenia solium, Taenia crassiceps, Toxocara canis, Schistosoma mansoni and Echinococcus granulosus) and cross-reactivities in human infections and immunized animals. Acta Trop. 2003;89:73-84.
9. Jacob CMA, Pastorino AC, Peres BA, Melo EO, Okay Y, Oselka GW. Clinical and laboratorial features of visceral toxocariasis in infancy. Rev Inst Med Trop Sao Paulo. 1994;36:19-26

10. Laemmli UK. Cleavage of structural proteins during the assembly of the head of bacteriophage T4. Nature. 1970;227:680-5.

11. Magnaval JF, Fabre R, Maurières P, Charlet JP, De Larrard B. Application of the Western blotting procedure for the immunodiagnosis of human toxocariasis. Parasitol Res. 1991;77:697-702

12. Magnaval JF, Glickman LT, Dorchies P, Morassin B. Highlights of human toxocariasis Korean J Parasitol. 2001;39:1-11.

13. Magnaval JF, Malard L, Morassin B, Fabre R. Immunodiagnosis of ocular toxocariasis using Western-blot for the detection of specific anti-Toxocara IgG and CAPTM for the measurement of specific anti-Toxocara IgE. J Helminthol. 2002;76:335-9.

14. Maizels RM, Gems DH, Page AP. Synthesis and secretion of TES antigen from Toxocara canis infective larvae. In: Lewis JW, Maizels RM, editors. Toxocara and toxocariasis: clinical, epidemiological and molecular perspectives. London: British Society for Parasitology; 1993. p. 141-50.

15. Matta VLR, Hoshino-Shimizu S, Dietze R, Corbett CEP. Detection of specific antibody isotypes and subtypes before and after treatment of American visceral leishmaniasis. J Clin Lab Anal. 2000;14:5-12.

16. Morales OL, López MC, Nicholls RS, Agudelo C. Identification of Toxocara canis antigens by Western blot in experimentally infected rabbits. Rev Inst Med Trop Sao Paulo. 2002;44:213-6.

17. Nunes CM, Tundisi RN, Garcia JF, Heinemann MB, Ogassawara S, Richtzenhain LJ. Cross-reactions between Toxocara canis and Ascaris suum in the diagnosis of visceral larva migrans by Western-blotting technique. Rev Inst Med Top Sao Paulo. 1997;39:253-6.

18. Obwaller A, Jensen-Jarolim E, Auer H, Huber A, Kraft D, Aspöck H. Toxocara infestations in humans: symptomatic course of toxocarosis correlates significantly with levels of IgE/anti-IgE immune complexes. Parasite Immunol.1998;20:311-7.

19. Primavera KSC, Hoshino-Shimizu S, Umezawa ES, Peres BA, Manigot DA, Camargo ME. Immunoglobulin A antibodies to Trypanosoma cruzi antigens in digestive forms of Chagas' disease. J Clin Microbiol. 1988;26:2101-4.

20. Roldán WH, Espinoza YA. Evaluation of an enzyme-linked immunoelectrotransfer blot test for the confirmatory serodiagnosis of human toxocariasis. Mem Inst Oswaldo Cruz. 2009; $104: 411-8$

21. Schantz P. Toxocara larva migrans now. Am J Trop Med Hyg. 1989;41:21-34

22. Smith HV. Antibody reactivity in human toxocariasis. In: Lewis JW, Maizels RM, editors. Toxocara and toxocariasis. Clinical, epidemiological and molecular perspectives. London: British Society for Parasitology; 1993. p. 91-109.

23. Smith H, Holland C, Taylor M, Magnaval JF, Schantz P, Maizels R. How common is human toxocariasis? Towards standardizing our knowledge. Trends Parasitol. 2009;25:182-8.

24. Towbin H, Staehelin T, Gordon J. Electrophoretic transfer of proteins from polyacrylamide gels to nitrocellulose sheets: procedure and some applications. Proc Natl Acad Sci USA. 1979;76:4350-54

Received: 4 June 2009

Accepted: 6 December 2010 